\title{
Abbreviations
}

I shall use the following abbreviations in referring to Wittgenstein's writings (references are to sections unless otherwise noted):

NB Notebooks, 1914-1916, 2d ed., ed. G. H. von Wright and G. E. M. Anscombe, trans. G. E. M. Anscombe (Chicago: University of Chicago Press, I979) (references to pages)

TLP Tractatus Logico-Philosophicus, trans. D. F. Pears and B. F. McGuinness (London: Routledge and Kegan Paul, 196r)

BB Blue and Brown Books (Oxford: Blackwell, 1958) (references to pages)

PG Philosophical Grammar, ed. Rush Rhees, trans. Anthony Kenny (Oxford: Blackwell, I974) (references to pages)

RFM Remarks on the Foundations of Mathematics, rev. ed., ed. G. H. von Wright, Rush Rhees, and G. E. M. Anscombe, trans. G. E. M. Anscombe (Cambridge: MIT Press, 1978)

PI Philosophical Investigations, 3 d ed., trans. G. E. M. Anscombe (New York: Macmillan, i 968) (references to sections of Part I unless otherwise indicated) 


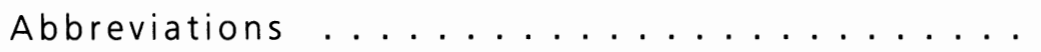

Z Zettel, ed. G. E. M. Anscombe and G. H. von Wright, trans. G. E. M. Anscombe (Oxford: Blackwell, I982)

OC On Certainty, ed. G. E. M. Anscombe and G. H. von Wright, trans. Denis Paul and G. E. M. Anscombe (Oxford: Blackwell, I969)

LWPP Last Writings on the Philosophy of Psychology, vol. I, ed. G. H. von Wright and Heikki Nyman, trans. C. G. Luckhardt and Maximilian A. E. Aue (Chicago: University of Chicago Press, 1982)

WLPP Wittgenstein's Lectures on Philosophical Psychology, 19461947 , notes by P. T. Geach, K. J. Shah, and A. C. Jackson, ed. P. T. Geach (New York: Harvester Wheatsheaf, I988) (references to pages) 


\section{The Continuity of}

Wittgenstein's Thought 
